\title{
GENDER DETERMINATION IN ADULT EGYPTIANS FROM COMPLETE AND FRAGMENTARY TIBIAE. AN ANTHROPOLOGICAL STUDY
}

\author{
$\mathcal{B} Y$ \\ Fonad, A.; Hegazi, E.; Abdel-Aziz, M. and Mokhtar, Z.* \\ Deparments of Forensic Medicine and Clinical Toxicology and Anatomy *. \\ Faculty of Medicine, Alexandria University, Egypt
}

\begin{abstract}
Sex determination from skeletal remains forms an imporlais component in the identification procedure. The aim of the present siidy was to establish siandards for determining sex front complete or frag. mentary fibiae in the adult Egypitans. The study was carried out on 100 tibial bones with previonsly known sex (64 males and 36 fenales). Seven tibial dimensions uere used; condylo-malleolar length; circumference at the nutrient foranen; minimal shafi circumference; anteroposterior dimension at numien foramch: trussterse dinension at nutrient foramen: proximal epipinyseal breadth: and distal epiphyseal brewhin. Fina discriminam functions were generafed; one using the seven variables, one using two variables, and wo employing one variable. The resuits showed that compleie tibiae can be sexed with $86.4 \%$ accuracy using the seven variables, and the same degree of accuracy was achieved using only two variables, while discriningu funcrions employing one variable showed accuracies of $66.7 \%$ and $77.3 \%$. The shuly concluded that the tibia (fragmentary or complete) can be used for sex determitation wim a high degree of ucewacy from $68.7 \%$ in, so $80.4 \%$.
\end{abstract}

Key wards: Sex characteristics; Discriminamt analysis; Tibia: Furensic anthropology: Egyps.

\section{INTRODUCTION}

"The record of organic evolution is largely written by the hard parts of the body, recognizable even after many years of death". This statement, by Krogman and Iscan (1986), reflects the role of the skeleton in estimating attributes such as age, sex, race, stature and disease.
The determination of sex is statistically the most important criterion, as it immediately excludes approximately half of the population whereas age, stature and race each provide points within a wide range of variables (Knight, 1991).

Sex determination from skeletal remains forms an important component in the identification procedure. Previous 
studies have demonstrated that populations differ from each other in size and proportion, and that these differences can affect the metric assessment of sex (Birkby, 1966; Iscan and Miller-Shaivitz, 1984; Macho, 1990).

However, sex identification sometimes becomes a difficult task for the forensic anthropologist, especially in the absence of the pelvis or the skull. These parts were relied upon in earlier studies because they exhibit the most obvious sexual dimorphism (DiBennardo and Taylor, 1983; Schulter-Ellis and Hayek, 1984).

A serious problem is that parts of the pelvis are relatively fragile and are often poorly preserved or completely missing from the skeletal remains. Also, sexing of the skull is largely dependent on the presence of complete craria (Kelley, 1979). Because of these limitations, other more resistant skeletal elements were used for sexing.

The tibia is the second largest bone in the skeleton. It is an ideal bone, for anthropological studies, because it resists erosive forces and keeps its anatomical shape for a long time, even after burial (Steyn and Iscan, 1997).

Hence, the aim of the present study was to establish standards for determining sex from the tibia, complete or fragmentary, among the adult Egyptians.

\section{MATERIAL AND METHODS}

The sample of the study consisted of 100 complete adult tibiae with known sex (64 males and 36 females). The sample was obtained from the Anatomy and Forensic Medicine Departments, Alexandria University. Abnormal or pathologically deformed bones were excluded from the study.

Seven osteometric dimensions werc taken, to the nearest millimeter, from each tibia (Iscan and Miller-Shaivitz 1984b): (Figure 1).

1- Tibial length = Condylo-malleolar length (CML):

This was measured from the medial malleolus to the lateral condyle.

2- Circumference at the nutrient foramen level (CNF).

3- Minimum shaft circumference (MSC).

4- Anteroposterior dimension at the nutrient foramen level (APNF).

5- Transverse dimension at the nutrient foramen level (TNF).

6- Maximal proximal epiphyseal breadth: which is the maximum distance between the condyles (MPEB).

7- Maximal distal epiphyseal breadth: which is the distance between the medial malleolus and the center of the fibular notch (MDEB). 
An osteometric board and sliding raliber were used for measuring all dimensions except circumferences which were measured using a plastic covered tape.

In order to test for bilateral variation in the measurements, dimensions of 20 sets of tibiae were subjected to a paired t-test. The difference was found to be insignificant at the 0.05 level, thus allowing the bones of both sides (right and left) to be grouped together.

However, only one bone from each skeleton, either left or right, has been included in the analysis.

Data were analysed using the SPSSX subroutine software (SPPSS Incorporated). Stepwise discriminant function analysis, employing the recorded measurements, was used to determine the optimal combination of variables for assessing sex. Variables, alone and in combinations, were also subjected to direct analysis to develop functions to allow sexing from complete and fragmentary tibiae (Nie et al., 1975).

\section{RESULTS}

The descriptive statistics for both sexes are demonstrated in table (1). This table shows that the index of dimorphism, which is mean of male measurements, divided by mean of female measurements and multiplied by 100 , is always greater than 100 , indicating that males have great- er tibial dimensions. The highest value of index is seen in the APNF, having a difference of $21.59 \%$.

The mean male measurements were statistically greater than the mean of female measurements. The difference between males and females was highly statistically significant in all variables indicating a strong sexual dimorphism (Table 1).

Once the existence of a strong sexual dimorphism was determined, discriminant analysis for all variables was done using Wilk's Lambda test (Table 2). The F-ratio shows that the APNF made the greatest contribution in the analysis, followed by the CNF and the CML. While the TNF contributed the least in the analysis.

A stepwise discriminant function was then performed where four discriminant functions were used. The selection of variable combination (s) was based on the DIRECT method according to the entry sequence into the stepwise analysis. The first function (Table 3) employed all seven variables. The second function (Table 4) employed two variables (CML and APNF), while the third and fourth functions were generated to determine sex from fragmentary tibiae, and used only a single variable (MPEB for upper end tibia, and MDEB for the lower end) (Table 5).

Standardized coefficients indicate the 
relative contribution of each variable to the function, while unstandardized coefficients are used for calculating discriminant function scores from the raw data. A dicriminant score is obtained by multiplying each variable with its unstandardized coefficient and adding them together along with the constant. If the score is greater than the sectioning point the individual is considered male, a lower score indicates a female.

In the first function (Table 3), where all seven variables were employed, the over- all-accuracy was $86.4 \%$ for both sexes. Classification accuracy was higher in males $(91.3 \%)$ than in females $(75 \%)$.

In the second function (Table 4), where two variables were combined (APNF and CML), surprisingly the same accuracy was obtained as that of function one, which used all seven variables $(86.4 \%)$.

Discriminant functions using a single variable (Table 5), namely functions 3 and 4, provided lower accuracies with $66.7 \%$ for MPEB and $77.3 \%$ for MDEB. 
Table (1): Sexual dimorphism and unifactorial statistics of the tibia in the

\begin{tabular}{|l|c|c|c|c|c|c|c|}
\hline \multirow{2}{*}{ Variable } & \multicolumn{2}{|c|}{$\begin{array}{c}\text { Male } \\
(\mathbf{n}=64)\end{array}$} & \multicolumn{2}{c|}{$\begin{array}{c}\text { Female } \\
(\mathbf{n}=36)\end{array}$} & \multicolumn{2}{l|}{ Sexual dimorphism } \\
\cline { 2 - 8 } & $\bar{X}$ & SD & $\bar{X}$ & SD & Index & $\mathbf{t}$ & $\mathbf{P}$ \\
\hline CML & 37.04 & 2.62 & 33.27 & 2.08 & 111.30 & $5.69^{*}$ & 0.000 \\
CNF & 9.39 & 0.72 & 8.19 & 0.83 & 114.70 & $5.95^{*}$ & 0.000 \\
MSC & 7.24 & 0.69 & 6.53 & 0.56 & 110.98 & $4.08^{*}$ & 0.000 \\
APNF & 3.49 & 0.38 & 2.87 & 0.35 & 121.59 & $6.12^{*}$ & 0.000 \\
TNF & 2.36 & 0.25 & 2.14 & 0.29 & 110.52 & $3.17^{*}$ & 0.002 \\
MPEB & 7.09 & 0.55 & 6.50 & 0.28 & 109.02 & $4.49^{*}$ & 0.000 \\
MDEB & 4.23 & 0.37 & 3.86 & 0.28 & 109.39 & $3.94^{*}$ & 0.000 \\
\hline
\end{tabular}

*Significant at $P \leq 0.05$

Index $=$ Male $\bar{X} /$ Female $\bar{X} \times 100$

$\bar{X}=$ Mean.

Table (2): Discriminant function analysis of variables of the tibia using

Wilk's Lambda and F-ratio.

\begin{tabular}{|l|c|c|c|}
\hline \multicolumn{1}{|c|}{ Variable } & Wilk's Lambda & F-ratio & p-value \\
\hline CML & 0.664 & $32.352^{*}$ & 0.000 \\
CNF & 0.644 & $35.434^{*}$ & 0.000 \\
MSC & 0.794 & $16.631^{*}$ & 0.000 \\
APNF & 0.625 & $38.415^{*}$ & 0.000 \\
TNF & 0.864 & $10.056^{*}$ & 0.002 \\
MPEB & 0.760 & $20.161^{*}$ & 0.000 \\
MDEB & 0.805 & $15.511^{*}$ & 0.000 \\
\hline
\end{tabular}

*Sig. at $\mathrm{P} \leq 0.05$ 
Table (3): Function 1 in stepwise analysis showing standardized and unstandardized coefficients and equation for sex determination from complete tibiae.

\begin{tabular}{|l|c|c|c|}
\hline \multicolumn{1}{|c|}{ Variable } & $\begin{array}{c}\text { Standardized } \\
\text { coefficients }\end{array}$ & $\begin{array}{c}\text { Unstandardized } \\
\text { coefficients }\end{array}$ & Accuracy \\
\hline CML & 0.578 & 0.234 & 1.574 \\
CNF & 1.189 & -1.716 & \\
APNF & -1.127 & 1.017 & \\
TNF & 0.380 & -0.466 & \\
MPEB & -0.123 & 0.173 & \\
MDEB & 0.084 & -0.262 & $86.4 \%$ \\
\hline Constant & 0.090 & -12.945 & \\
Sectioning point & & 0.63 & \\
\hline
\end{tabular}

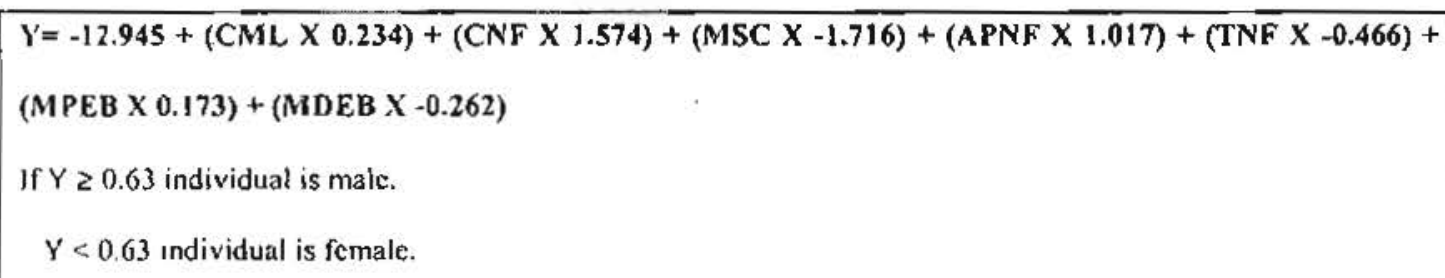


Table (4): Function 2 in stepwise analysis showing standardized and unstandardized coefficients and a second equation for sex determination from complete tibiae.

\begin{tabular}{|l|c|c|c|}
\hline \multicolumn{1}{|c|}{ Variable } & $\begin{array}{c}\text { Standardized } \\
\text { coefficients }\end{array}$ & $\begin{array}{c}\text { Unstandardized } \\
\text { coefficients }\end{array}$ & Accuracy \\
\hline CML & 0.471 & 0.191 & \\
APNF & 0.651 & 1.741 & \\
\hline Constant & & -12.59 & \multirow{2}{*}{$86.4 \%$} \\
Sectioning & & 0.55 & \\
point & & & \\
\hline
\end{tabular}

$Y=-12.59+($ CML X 0.191) $+($ APNF X 1.741)

If $Y \geq 0.55$ individual is male.

$\mathrm{Y}<0.55$ individual is female.

Table (5): Function 3 and 4 in stepwise analysis showing unstandardized coefficients and equation for sex determination from upper and lower ends of tibiae.

\begin{tabular}{|c|c|c|c|}
\hline Variable & $\begin{array}{c}\text { Unstandardiz } \\
\text { ed } \\
\text { coefficients }\end{array}$ & $\begin{array}{c}\text { Accurac } \\
y\end{array}$ & Equation \\
\hline MPEB & 2.048 & & \multirow{2}{*}{$\begin{array}{l}Y=14.157+\text { (MPEB } X \\
\mathbf{2 . 0 4 8 )} \\
Y \geq 0.36 \text { male } \\
Y<0.36 \text { female }\end{array}$} \\
\hline $\begin{array}{l}\text { Constant } \\
\text { Sectioning } \\
\text { point }\end{array}$ & $\begin{array}{c}-14.157 \\
0.36\end{array}$ & $66.7 \%$ & \\
\hline MDEB & 2.901 & & \multirow{2}{*}{$\begin{array}{l}Y=\quad-11.938+(\mathrm{MDEB} \\
\mathrm{X} 2.901) \\
\mathrm{Y} \geq 0.32 \text { male } \\
\mathrm{Y}<0.32 \text { female }\end{array}$} \\
\hline $\begin{array}{l}\text { Constant } \\
\text { Sectioning } \\
\text { point }\end{array}$ & $\begin{array}{c}-11.938 \\
0.32\end{array}$ & $77.3 \%$ & \\
\hline
\end{tabular}



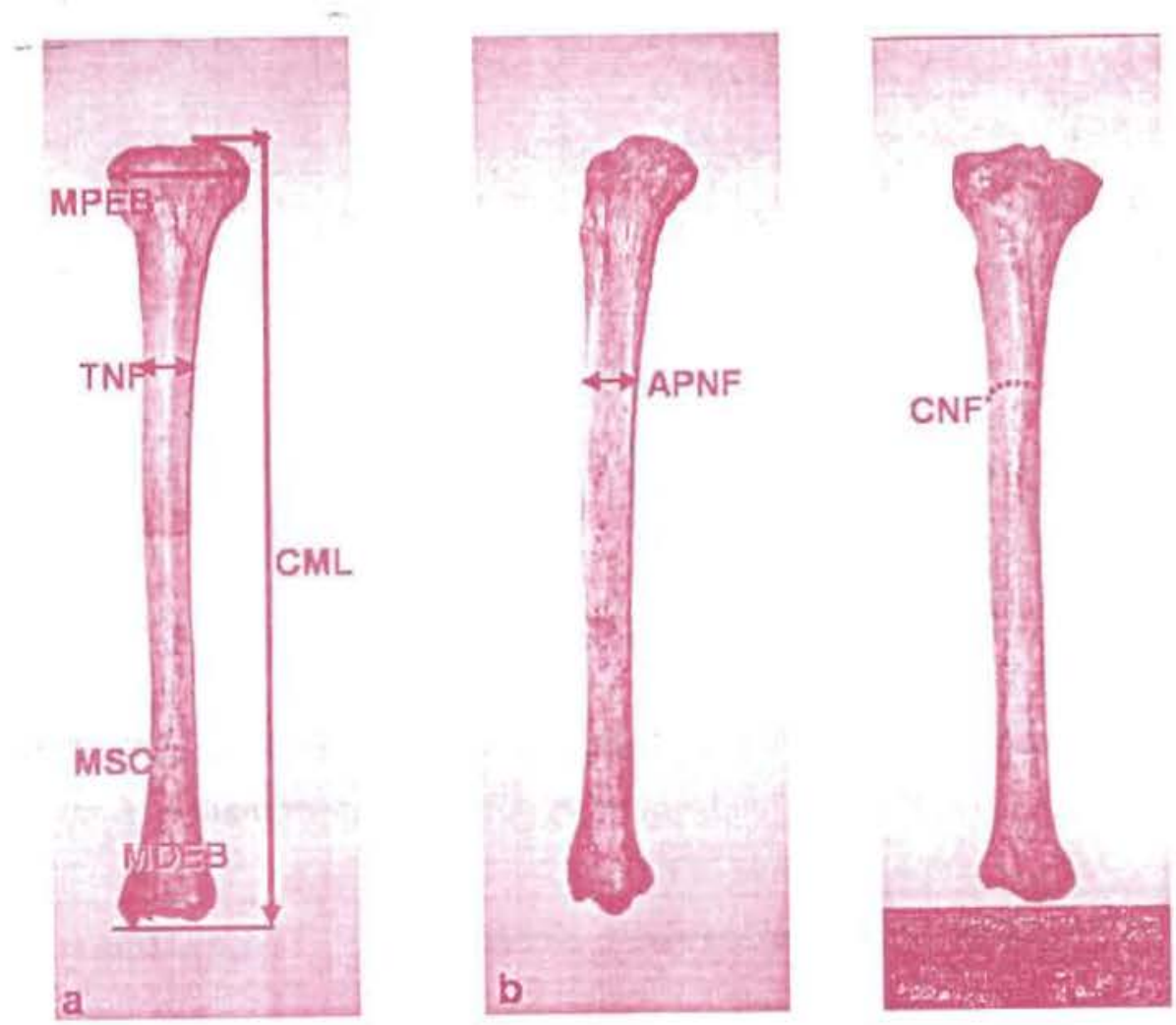

Figure (1): Photograph of left libia (a: anterior surface view. b: lateral vicw. c: posterior surface view) shows the osteometric dimensions used in the study. 


\section{DISCUSSION}

Skeletal biologists have long recognized that each population group requires its own specific standards for accurate determination of sex, and that it is necessary to calculate discriminant functions on samples from different geographic areas. Iscan et al. (1994) have shown that, overtime, changes can occur in a single population due to differences in nutrition, disease or population mobility, and that specific discriminant functions must be developed to take into account temporal changes within a particular population.

The tibia is a large and robust bone. It is known to preserve its anatomy, even after burial, and thereby a good choice for arthropological studies. In the present study, the mean values for the seven tibial dimensions measured were significantly higher in males than females. This indicates strong sexual dimorphism in the analyzed sample and the usefulness of these variables in evaluating morphological differences between sexes.

It is known that the average male skeleton is larger and heavier than the average female, although the magnitude of difference varies from one population to another. This sex difference can be the result of genetic factors, environmental factors affecting growth and development, or the interaction of both (Trancho et al., 1997).
It is also affected by the health status of the sample. Although it is not known which dimensions would be most affected by an inadequate diet, it is possible that differential growth factors affect the differences between the sexes (William et al., 1989). This theory agrees with the firidings of Iscan and Miller-Shaivitz, (1984a) whio reported a higher dimorphism in blacks than whites, indicating that determination of sex required a consideration of nutritional, physical and genetic (racial) factors.

In the present study the overall accuracy in sex determination, using all seven variables, was $86.4 \%$, with classification accuracy higher in males than in females $(91.3 \%$ and $75 \%$ respectively). This finding agrees with that of Iscan et al., (1994). They had a classification accuracy of $96 \%$ and $79 \%$ in males and females, respectively among Japanese population. The gap in the accuracy between sexes is probably due to the combined effect of unequal sample size and intrasex variations.

In discriminant analysis, the greatest contribution was for the anteroposterior dimension at the nutrient foramen level. It is believed that breadth dimensions provide better sex separation than length. Black (1978) attributed this to differential bone remodeling, between males and females, that leads to greater cortical bone development during adolescence that remains unchanged throughout adulthood. 
This differential bone development primárily affects breadth and circumference measurements.

Another great contribution was for the condylo malleolar length (CML), while the maximal epiphyseal breadth had moderate contribution. Steyn and Iscan (1997) reported that the distal breadth provided the best discrimination in South African whites. They attributed this finding to the theory of DiBennardo and Taylor (1982), who suggested that epiphyseal measurements are more reliable indicators of sex because the functional demands of weight and musculature concentrate on these parts of the bone.

In the present study, sexing of complete tibiae using all seven variables gave an accuracy of $86.4 \%$ and when two variables were employed, namely CML and APNF, based on the variables selected by the stepwise discriminant function analysis, the same accuracy was obtained. This was not in agreement with the results of Slaus and Tomicic (2005) who achieved lower accuracies using two variables. This suggests that function 2 (employing two variables) could be considered in sexing of well-preserved, complete tibiae instead of function 1 (employing all seven variables).
It is a common experience for the forensic expert to be confronted with poorly preserved or fragmentary bones, thus, it is necessary to have sex determination techniques applicable to various parts of the bone. In the present study the proximal and distal epiphyseal breadths were chosen to be employed separately in two discriminant functions ( 3 and 4 ).

The results revealed accuracy in sex determination of $66.7 \%$ and $77.3 \%$ respectively, which could be used in sexing fragmentary tibiae.

In conclusion, the tibia is considered a good source for sex determination in the adult Egyptians, with excellent accuracy in case of complete, wellpreserved bones $(86.7 \%)$. Furthermore, the results proved sexing from fragmentary tibiae, with degrees of accuracies (up to $77.3 \%$ ), which would be enhanced if used in association with other available data.

\section{Acknowledgement :}

We would like to express our gratitude to Dr. Heba M. Fouad, lecturer of Public Health, Faculty of Medicine, University of Alexandria, for her great assistance in the statistical analysis of the study. 


\section{REFERENCES}

Birkby W. H. (1966) : "An evaluation of race and sex identification from cranial measurements". Am. J. Phys. Anthropol., 21: $21-7$.

- Black T. K. (1978) : "A new method for assessing the sex of fragmentary skeletal remains: femoral shaft circumference". Am. J. Phys. Anthropol., 48: 227-32.

DiBennardo R. and Taylor J. V. (1982) : "Classification and misclassification in sexing the black femur by discriminant function analysis". Am. I. Phys. Anthropol., 58: 145-51.

DiBennardo, R. and Taylor, J. V. (1983) : "Multiple discriminant function analysis of sex and race in post cranial skeleton". Am. J. Phys. Anthropol., 61: 305-14.

Iscan, M. Y, and Miller-Shaivitz, P. (1984) (a): "Determination of sex from the femur in blacks and whites". Coll. Anthropol., 8: 169-77.

Iscan, M. Y. and Miller-Shaivitz, P. (1984) (b) : "Discriminant function sexing of the tibia". J. Forensic Sci., 4: 1087-93.

Iscan, M. Y,; Yoshino, M. and Kato, S. (1994) : "Sex determination from the tibia: Standards for contemporary Japan". J. Forensic Sci., 39: 785-92.
Kelley, M. A. (1979) : "Sex determination with fragmented skeletal remains": J. Forensic Sci., 24: 154-8.

Knight, B. (1991) : The establishment of identity of human remains. In: Forensic Pathology. London, Melbourne, Auckland, Edward Arnold, P.P. 87- 122.

Krogman, W. M. and Iscan, M. Y. (1986) : The Human Skeleton in Forensic Medicine. Charles C. Thomas, Springfield, IL.

Macho, G. A. (1990) : "Is sexual dimorphism in the femur a population specific phenomenon". Zmorphol. Anthropol., 78: 229-42.

Nie, N. H.; Hull, C. H.; Jenkins, J. G.; Steinbrenner, K. and Bent, D. H. (1975) : Statistical Package for the Social Sciences. McGraw-Hill, New York.

Schulter-Ellis, F. P. and Hayek, L. C. (1984) : "Predicting sex and race with an acetabulum-pubis index". Coll. Anthropol., 8: 155-62.

Slaus, M. and Tomicic, Z. (2005) : "Discriminant function sexing of fragmentary and complete tibiae from medieval Croatian Sites". Forensic Sci. Int., 147: 147-52.

Steyn, M. and Iscan, M. Y. (1997) : "Sex determination from the femur and tibia in 
South African whites". Forensic Sci. Int., 90: 111-9.

Trancho, G. J.; Robledo, B.; LopezBueis, I. and Sanchez, A. (1997) : "Sexual determination of femur using discriminant function analysis of a Spanish population of known sex and age". J. Forensic Sci., 42: 181-5.
Standring, S. (2005) : Gray's Anatomy. 39th ed., Churchill Livingstone. Edinburgh, London, New York, P.P. 1490-1493.

William, P. L.; Warwick, R.; Dyson, M. and Bannister, L. H. (1989) : Gray's Anatomy. Churchill Livingstone, Edinburgh. 


\title{
نحديد النوع فى الهصريبين البالغبين عن عظمة القصبة أو أجزائها.

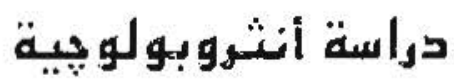

\author{
المنتركون في البهن \\ ב. د. إيهـان حبــازلى

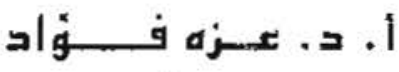

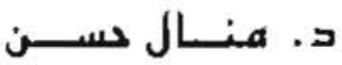

$$
\text { من أتسام الطب الشرعى والسمرم الإكلينيكية والتشريح* كلبة الطب - بامعن الإسبكدرية }
$$

بشكل تحديد النوع من البقايا العظمبة جز مأ هامأ من عملية الاستعران. ولهذا كان الهدف من الدراسة مو رضع معايير لتحديد الموع عن. عظمة التصبة الكاملة أر أجزانها فى المصريين البالغين.

ر أجريت البراسة على عدد مانة عظعة نصبة كاملة بعروفة النرع ( 64 ذكر, و36 أنشى) وتم قياس سبعة أبعاد على العظمن شعلت ألطول

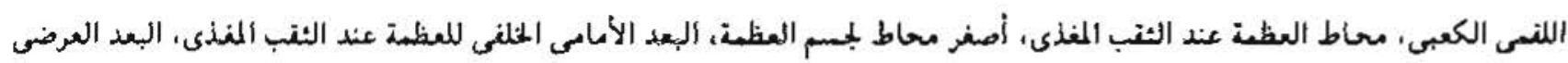
عند الثتب المفذى رعرض المثانة الدانية بالجز ، العلوى رالتصرى بالجز • السفلو. من العظم.

نم تطبيق أربع وظائف تيزية تحليلية فى الدراسة الإحصانبة لهذا البحث حيث استخدم فى الوظبفة الأرلى سبع أبعاد لعظمة القصبة رنى

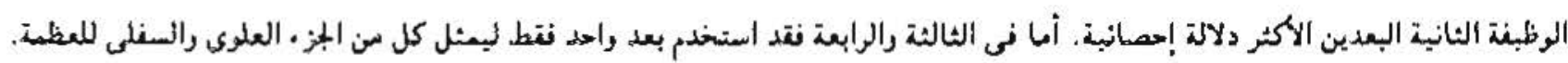
وتد أظهرت اللدراسة أن عظمة الثتصبة الكاملة يكن يحديد نرعها بدقة تصل إلى 86.4 باستخدأز السبعة أبعاد وينفس النسبة من الدنة باستخدام بعدين نتط ( الطول اللتهى الكعبى ر البعد الأمامى الخلفى للعظمة عند الثتب المغذى) بينها أظهر التمبيز انوظيفى الإهصانى

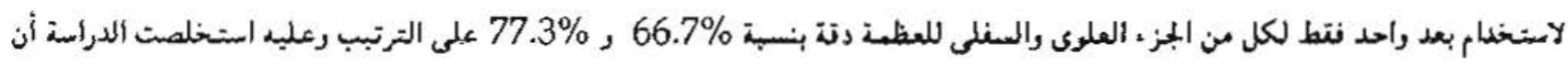

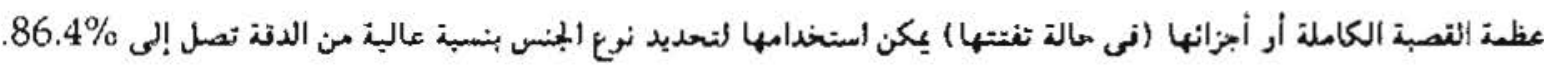

